\title{
Optical Properties of (AR) Multilayer Thin Film for Solar Cell Application
}

\author{
C. Gopinathan, M. Kavitha and P.Pandi \\ P.G. and Research Department of Physics, The Madura College, Madurai-625011, India
}

\begin{abstract}
We have been prepared Semiconducting oxide material like $\mathrm{TiO}_{2}, \mathrm{SiO}_{2}, \mathrm{TiO}_{2}-\mathrm{SiO}_{2}$ and $\mathrm{TiO}_{2} / \mathrm{SiO}_{2}$ thin films for taken different composition by using hydrothermal method. All these elements were deposited on the glass substrate. In this films are acted on the $p$ and $n$ type working with the majority carrier are recombination of electron and hole .This material is $N$ type but it will acted p-type Ti and Si. Thin films were Characterized by scanning electron microscope (SEM), X-ray diffraction (XRD), and UV. From the UV Studies we have analysis the energy gap $\left(E_{g}\right)$, refractive index $(n)$ and extinction co efficient.
\end{abstract}

Keywords: $\mathrm{TiO}_{2}, \mathrm{SiO}_{2}, \mathrm{TiO}_{2}-\mathrm{SiO}_{2}$ and $\mathrm{TiO}_{2} / \mathrm{SiO}_{2}$ thin films, $\mathrm{XRD}$, UV and $\mathrm{SEM}$

\section{Introduction}

Metal oxides, such as $\mathrm{TiO}_{2}, \mathrm{SiO}_{2}$ are materials with high surface areas that exhibit exceptional chemical reactivity compared with commercial metal oxides. Metal oxide nanoparticles may potentially be inexpensive alternatives to carbon nanotubes with superior properties for many applications including catalysis, separation, gas storage, energy conversion, drug release, sensing and environmental protection, and biocompatible nanocomposites. The modified form of $\mathrm{TiO}_{2}$ composites such as $\mathrm{TiO}_{2}-\mathrm{SiO}_{2}, \mathrm{TiO}_{2} / \mathrm{SiO}_{2}$ are interest for their potential application, such as electrolytes in dye-sensitized solar cells, anti reflection coating, photocatalysts and so on [1-7].

\section{Materials and Methods}

For preparation of $\mathrm{TiO}_{2}-\mathrm{SiO}_{2}$ as precursor solution, Titanium (IV) isopropoxide (TTIP, SigmaAldrich), Sodium Meta silicate, Ethanol and Hydrochloric acid were used as raw materials. The $\mathrm{TiO}_{2}$ was produced by mixing of TTIP and ethanol in the ratio of 1:5. This solution was stirred under $0^{\circ} \mathrm{C}$ (ice bath) for $6 \mathrm{hrs}$.The resultant solution was transferred into the autoclave, and aging, annealing temperature are given below the table1.1. The $\mathrm{SiO}_{2}$ was produced by mixing $0.1 \mathrm{M}$ of SMS (Sodium Meta Silicate) and 20ml of ethanol.

Table.1. The aging, annealing temperature

\begin{tabular}{|c|c|c|c|}
\hline Samples & $\begin{array}{l}\text { Stirring } \\
\text { temperature }\left({ }^{\circ} \mathbf{C}\right) / \mathbf{h r s}\end{array}$ & $\begin{array}{l}\text { Aging } \\
\text { temperature }\left({ }^{\circ} \mathbf{C}\right) / \mathbf{h r s}\end{array}$ & $\begin{array}{l}\text { Annealing } \\
\text { temperature }\left({ }^{\circ} \mathbf{C}\right) / \mathbf{h r}\end{array}$ \\
\hline $\mathrm{TiO}_{2}$ & $70 / 6$ & $120 / 48$ & $300 / 1$ \\
\hline $\mathrm{SiO}_{2}$ & $70 / 6$ & $120 / 48$ & $300 / 1$ \\
\hline $\mathrm{TiO}_{2}-\mathrm{SiO}_{2}$ & $70 / 6$ & $120 / 24$ & $300 / 1$ \\
\hline $\mathrm{TiO}_{2} / \mathrm{SiO}_{2}$ & $70 / 6$ & $120 / 24$ & $300 / 1$ \\
\hline
\end{tabular}

\subsection{Structural analysis:}

\section{Result and Discussion}

In hydrothermally prepared $\mathrm{TiO}_{2}$ (Fig.1a) the peak positions and their relative intensities are consistent with the standard diffraction patterns of srilankite- $\mathrm{TiO}_{2}$ (JCPDS card \# 23-1446). It has a main peak at $31.3^{\circ}$ corresponding to the (111) plane. The peak position at $26.5^{\circ}$ and $31.3^{\circ}$ are in accordance with the $\mathrm{TiO}_{2}$ srilankite phase. The lattice parameter of the pure $\mathrm{TiO}_{2}$ [(orthorhombic) $\mathrm{a}=4.55 \AA$; $\mathrm{b}=5.46 \AA \mathrm{c}=4.92 \AA$ ] are also in accordance with the reported value (JCPDS card \# 23-1446). Similarly $\mathrm{TiO}_{2}-\mathrm{SiO}_{2}(\mathrm{Fig} 1 \mathrm{~b})$ and $\mathrm{TiO}_{2} / \mathrm{SiO}_{2}$ (Fig.1c) thin film was prepared by the hydrothermal method. The peak position confirms the deposited elements. $\mathrm{TiO}_{2}-\mathrm{SiO}_{2}$ the peak positions and their relative intensities are consistent with the standard diffraction patterns of brookite- modified $\mathrm{TiO}_{2}$ (JCPDS card \#03-0380) and also brookite- $\mathrm{TiO}_{2} / \mathrm{SiO}_{2}$ (JCPDS card \# 291360). From the Fig.1b. the peak position ( 86 r 0 ) corresponds to the $\mathrm{SiO}_{2},\left(\begin{array}{lll}1 & 1 & 1\end{array}\right)$ and $\left(\begin{array}{lll}1 & 2 & 1\end{array}\right)$ corresponds to brookite- $\mathrm{TiO}_{2}$. Form the Fig.1c. the peak value ( $\left.\begin{array}{lll}1 & 1 & 1\end{array}\right)$ corresponds to the glass substrate, and $\left(\begin{array}{lll}2 & 2 & 0\end{array}\right),\left(\begin{array}{ll}0 & 2\end{array} 2\right.$ ), ( $\left.\begin{array}{lll}0 & 3 & 2\end{array}\right)$ and ( 1223 ) corresponds to the brookite - $\mathrm{TiO}_{2}$. 
Fig.1.XRD Spectrum for the a) $\mathrm{TiO}_{2}$, b) $\mathrm{TiO}_{2}-\mathrm{SiO}_{2}$ and c) $\mathrm{TiO}_{2} / \mathrm{SiO}_{2}$ nano thin film prepared by hydrothermal method

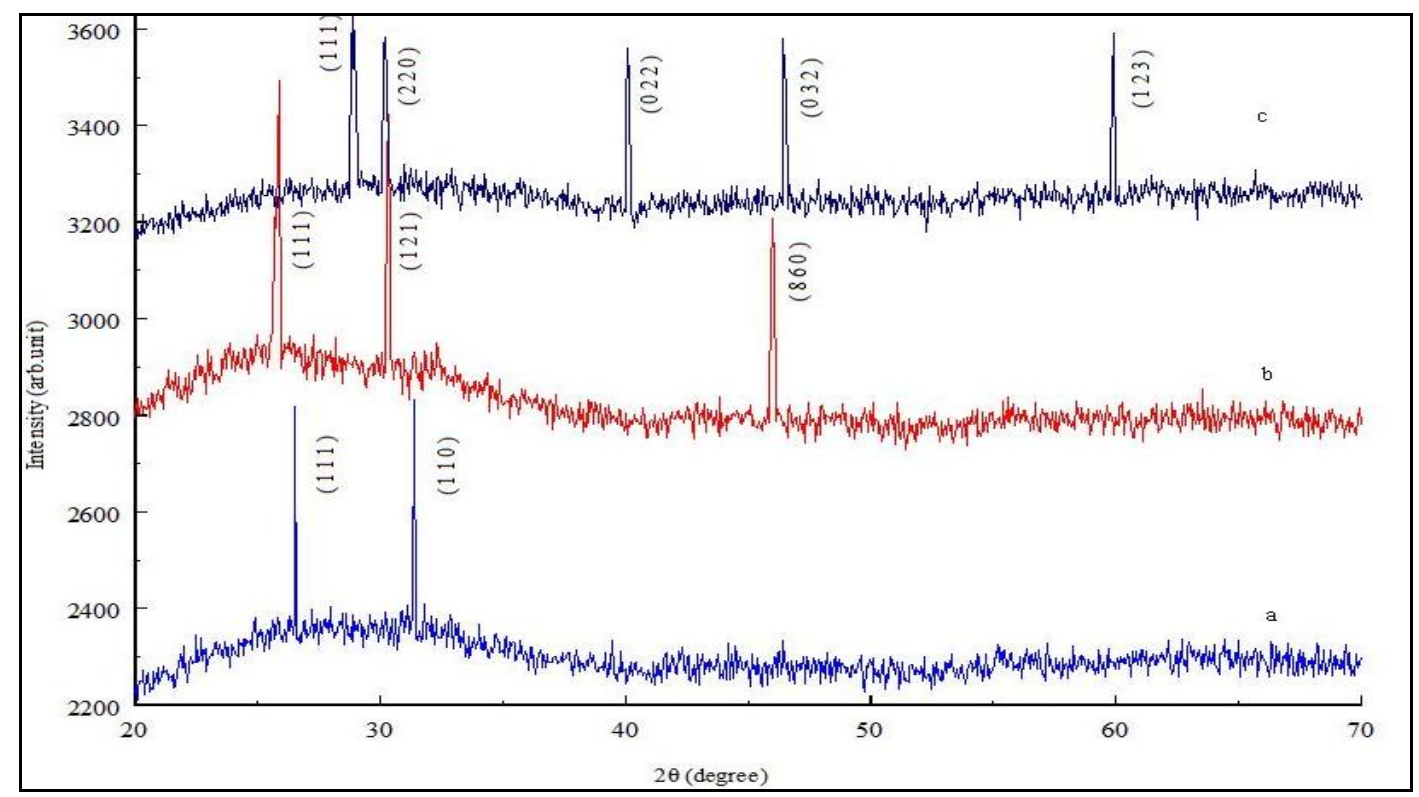

\subsection{UV Characterization}

The extrapolation graphs (Fig.3) indicate a direct optical transition and evaluated energy band gap of the prepared thin films. The optical band gap values of the, brookite type $\mathrm{TiO}_{2}-\mathrm{SiO}_{2}, \mathrm{TiO}_{2} / \mathrm{SiO}_{2}$ thin film very slightly increased to $3.6 \mathrm{eV}$ and $3.8 \mathrm{eV}$ [8-9]. The Fig.2 the blue shift of the absorption edge is observed that corresponds to the increase of the band gap $\left(\mathbf{E}_{\mathrm{g}}\right)$ value for the $\mathrm{TiO}_{2}, \mathrm{TiO}_{2}-\mathrm{SiO}_{2}$, and $\mathrm{TiO}_{2} / \mathrm{SiO}_{2}$. $\mathrm{TiO}_{2}$ mixing with $\mathrm{SiO}_{2}$ (Fig.2) causes appearance of the absorption in the near visible spectral range due to the direct optical transition from valence band to conduction band.
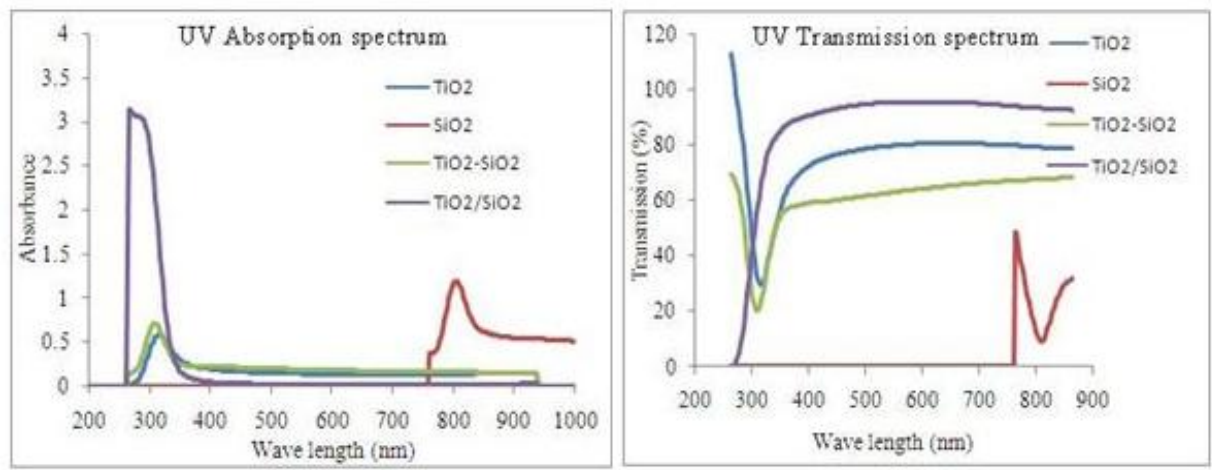

Fig .2. UV Absorption and transmission spectrum for the hydrothermally prepared thin film
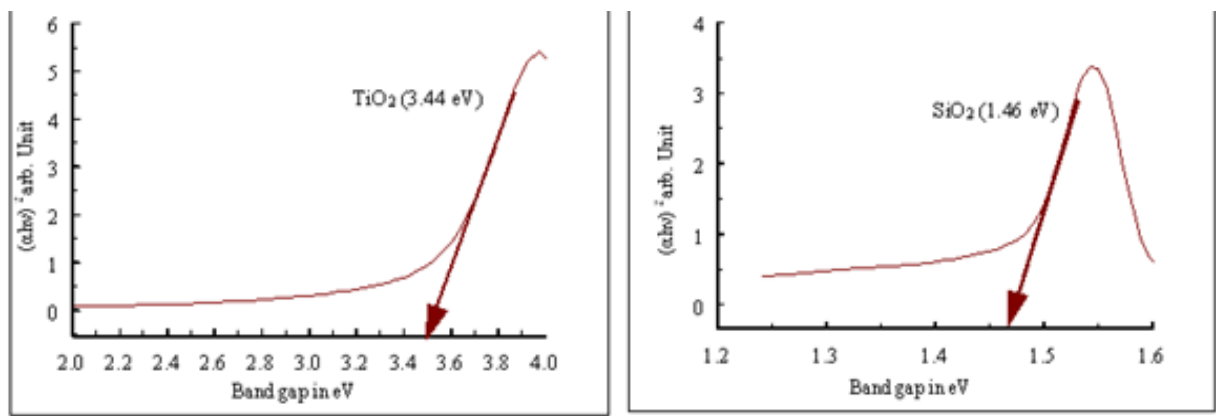

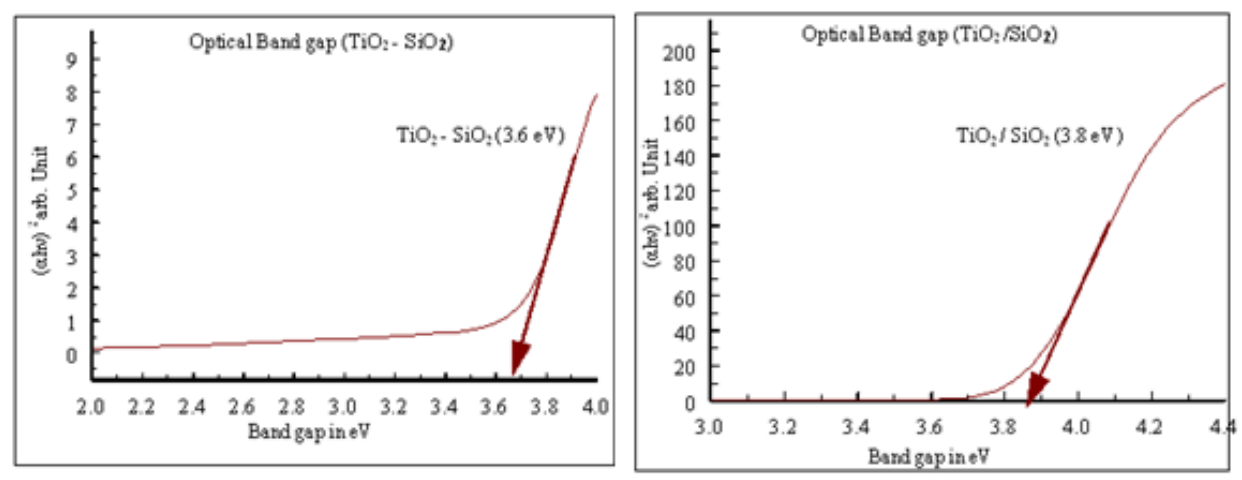

Fig.3. Optical band gap of the hydrothermally prepared thin film

\subsubsection{Optical Properties}

The optical study of a solid concerns not only physical phenomena such as refraction, reflection, transmission, absorption, polarization, interference, of light but also the interactions of photon energy with matter and the consequent changes in the electron states. From reflection, transmission and absorption processes it is possible to evaluate the optical constants such as (1).Refractive index (n) and Absorption index or Extinction co-efficient $(\mathbf{k}),(\mathbf{2})$. Thickness of the thin film (t), (3). Optical Band gap $\left(\mathbf{E}_{\mathbf{g}}\right)$ and (4). Absorption coefficient $(\boldsymbol{\alpha})$. All these parameters were calculated by hydrothermally prepared thin films and tabulated, as seen in Table.2 [8-9]. $\mathrm{TiO}_{2}-\mathrm{SiO}_{2}, \mathrm{TiO}_{2} / \mathrm{SiO}_{2}$ Anti reflection coating layer is used in a solar cell, low reflectance should be confirmed.

Table.2. Calculated values of $\mathbf{n}, \mathbf{k}, \mathbf{t}$ and $\mathbf{E}_{\mathbf{g}}$ for hydrothermally prepared thin films

\begin{tabular}{|c|c|c|c|c|c|}
\hline Samples & Reflectance(R) & $\begin{array}{c}\text { Refractive } \\
\text { index (n) }\end{array}$ & $\begin{array}{c}\text { Extinction } \\
\text { coefficient(k) }\end{array}$ & $\begin{array}{c}\text { Thickness } \\
\text { (t) }\end{array}$ & $\begin{array}{c}\text { Optical Band } \\
\text { gap Eg (eV) }\end{array}$ \\
\hline $\mathrm{TiO}_{2}$ & 0.11878 & 2.05178 & 0.145318 & $391.2 \mathrm{~nm}$ & 3.44 \\
\hline $\mathrm{SiO}_{2}$ & 0.0638 & 1.675895 & 0.763672 & $4.17 \mu \mathrm{m}$ & 1.46 \\
\hline $\mathrm{TiO}_{2}-\mathrm{SiO}_{2}$ & 0.08077 & 1.794079 & 0.175334 & $513.3 \mathrm{~nm}$ & 3.6 \\
\hline $\mathrm{TiO}_{2} / \mathrm{SiO}_{2}$ & 0.1 & 1.924951 & 0.66021 & $254.0 \mathrm{~nm}$ & 3.8 \\
\hline
\end{tabular}

\subsection{Morphological Analysis}

The microstructure of the $\mathrm{TiO}_{2}$ nanoparticles synthesized by hydrothermal method in the present studied was observed by SEM which is shown in Fig.4. The prepared sample shows particle with great aggregation. The size of the particle is around $500 \mathrm{~nm}$. The shape of the particle is not uniform and it looks like spherical in shape. The microstructure of the thin film sample annealed at $300^{\circ} \mathrm{C}$ shows reduction in the agglomeration (Fig.4.c). The formed nanoparticles are visible clearly. Here also the shape of the particle was observed as sphere like morphology with different size around 230nm. (Fig.4d). shows that the size distribution is almost uniform compared to other particles and the size of the particle is almost $240 \mathrm{~nm}$. From the morphological analysis it is found that, the sample prepared by hydrothermal method improves the uniformity of the samples. 

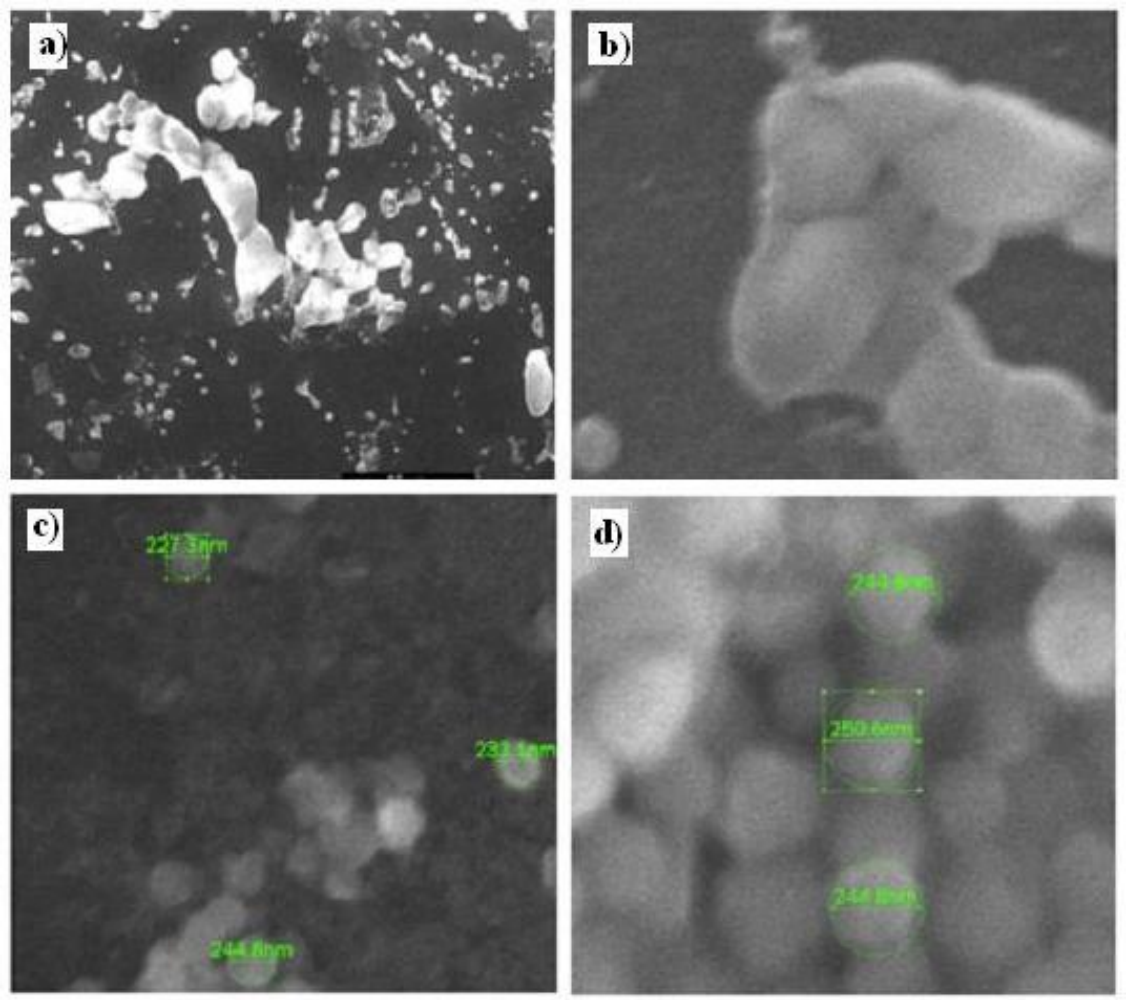

Fig.4.SEM image of a) \& b) $\mathrm{TiO}_{2}$ c) $\mathrm{TiO} 2-\mathrm{SiO}_{2}$ and d) $\mathrm{TiO}_{2} / \mathrm{SiO}_{2}$

\section{Conclusion}

Synthesis and characterization of the photovoltaic materials (Nano structured of $\mathrm{TiO}_{2}, \mathrm{SiO}_{2}, \mathrm{TiO}_{2}-\mathrm{SiO}_{2}$ and $\mathrm{TiO}_{2} / \mathrm{SiO}_{2}$ ), is presented. The optical, structural, and morphological studies of the prepared thin films were analyzed.

The optical band gap of the prepared $\mathrm{TiO}_{2}-\mathrm{SiO}_{2}$ and $\mathrm{TiO}_{2} / \mathrm{SiO}_{2}$ is slightly increases due to reduction of the particles size. Since the reflectance of the $\mathrm{TiO}_{2}-\mathrm{SiO}_{2}$ and $\mathrm{TiO}_{2} / \mathrm{SiO}_{2}$ is low, then the material are suitable for antireflection coating. Then the $\mathrm{TiO}_{2}, \mathrm{SiO}_{2}, \mathrm{TiO}_{2}-\mathrm{SiO}_{2}$ and $\mathrm{TiO}_{2} / \mathrm{SiO}_{2}$ thin film has good photocatalytic property. From the SEM, the uniformity of the particle size of $\mathrm{TiO}_{2}-\mathrm{SiO}_{2}$ and $\mathrm{TiO}_{2} / \mathrm{SiO}_{2}$ is higher than that $\mathrm{TiO}_{2}$. The Srilankite structure is observed in the prepared $\mathrm{TiO}_{2}$ thin film. Brookite structure is also observed in the prepared $\mathrm{TiO}_{2}-\mathrm{SiO}_{2}$ and $\mathrm{TiO}_{2} / \mathrm{SiO}_{2}$ thin films.

Hence, we can conclude that, hydrothermally prepared thin film shows better optical, structural, and morphological and photocatalytic property. Anti reflection coating layer of $\mathrm{TiO}_{2}-\mathrm{SiO}_{2}$ and $\mathrm{TiO}_{2} / \mathrm{SiO}_{2}$ is suitable for in a solar cell fabrication.

\section{References:}

[1]. Mindaugas andrulevičius,sigitas tamulevičius, yuriy gnatyuk3, Nadija vityuk, natalia smirnova, anna eremenko, Mater.Sci.14,2008, 1 .

[2]. Abbas Hodroj,Odette Chaix-Pluchery, Marc Audier, Ulrich Gottlieb and Jean-Luc Deschanvres J .Mater.Res. 23, (3), $2008,755$.

[3]. Jong-Gul Yoon, Hun Kyoo Oh and Young Jik Kwag, J.Kor. Phys. Soci. 33,(6),1998, 699-704.

[4]. Emil Indrea, Anca Peter, Danut T Silipas, Simina Dreve, Ramona-Crina Suciu, Marcela Corina Rosu, Virginia Danciu and Veronica Cosoveanu, J. Phys. Conf. Series 182, 2009, 012066.

[5]. F. Gracia , F. Yubero , J.P. Holgado , J.P. Espinos, A.R. Gonzalez-Elipe ,T. Girardeau, Else.Thin Solid Films 500 ,2006, 19 -26

[6]. A. Thangaraj, M.J. Eapen, S. Sivasanker, and P. Ratnasamy ZEOLITES, 12, 1992, 943-950.

[7]. Jung Wook Lim, Sun Jin Yun, and Je Ha Kim, ETRI Journal, 31, (6), 2009, 675-679.

[8]. A. SLAV, 6, (3), 2011, $915-920$.

[9]. Mindaugas ANDRULEVICIUS,Sigitas TAMULEVICIUS,Yuriy GNATYUK,Nadija VITYUK,Natalia SMIRNOVA,Anna EREMENKO, Mat.Sci.14,(1),2008,8-14. 